\title{
Analysis of three decades of land cover changes in the Maputaland Coastal Plain, South Africa
}

\begin{tabular}{|c|c|}
\hline \multicolumn{2}{|c|}{$\begin{array}{l}\text { Authors: } \\
\text { Manish Ramjeawon } \\
\text { Molla Demlie }^{1,2} \\
\text { Michele L. Toucher } \\
\text { Susan Janse van Rensburg }\end{array}$} \\
\hline \multicolumn{2}{|c|}{$\begin{array}{l}\text { Affiliations: } \\
{ }^{1} \text { South African Environmental } \\
\text { Observation Network, } \\
\text { Pietermaritzburg, South } \\
\text { Africa }\end{array}$} \\
\hline \multicolumn{2}{|c|}{$\begin{array}{l}{ }^{2} \text { Centre for Water Resources, } \\
\text { College of Agriculture, } \\
\text { Engineering and Science, } \\
\text { University of KwaZulu-Natal, } \\
\text { Pietermaritzburg, } \\
\text { South Africa }\end{array}$} \\
\hline \multicolumn{2}{|c|}{$\begin{array}{l}{ }^{3} \text { Department of Geology, } \\
\text { College of Agriculture, } \\
\text { Engineering and Science, } \\
\text { University of KwaZulu-Natal, } \\
\text { Pietermaritzburg, } \\
\text { South Africa }\end{array}$} \\
\hline \multicolumn{2}{|c|}{$\begin{array}{l}\text { Corresponding author: } \\
\text { Manish Ramjeawon, } \\
\text { mramjeawon@gmail.com }\end{array}$} \\
\hline \multicolumn{2}{|c|}{$\begin{array}{l}\text { Dates: } \\
\text { Received: } 08 \text { June } 2020 \\
\text { Accepted: } 18 \text { Aug. } 2020 \\
\text { Published: } 09 \text { Nov. } 2020\end{array}$} \\
\hline \multicolumn{2}{|c|}{$\begin{array}{l}\text { How to cite this article: } \\
\text { Ramjeawon, M., Demlie, M., } \\
\text { Toucher, M.L. \& Janse van } \\
\text { Rensburg, S., 2020, 'Analysis } \\
\text { of three decades of land } \\
\text { cover changes in the } \\
\text { Maputaland Coastal Plain, } \\
\text { South Africa', Koedoe 62(1), } \\
\text { a1642. https://doi. } \\
\text { org/10.4102/koedoe. } \\
\text { v62i1.1642 }\end{array}$} \\
\hline \multicolumn{2}{|c|}{$\begin{array}{l}\text { Copyright: } \\
\text { C 2020. The Authors. } \\
\text { Licensee: AOSIS. This work } \\
\text { is licensed under the } \\
\text { Creative Commons } \\
\text { Attribution License. }\end{array}$} \\
\hline Read onlir & \\
\hline atipla & $\begin{array}{l}\text { Scan this QR } \\
\text { code with your } \\
\text { smart phone or } \\
\text { mobile device } \\
\text { to read online. }\end{array}$ \\
\hline
\end{tabular}

The northern half of the Maputaland Coastal Plain (MCP) of South Africa has undergone significant change in land-use over the last five decades, including afforestation, agriculture and rural settlements. To understand the extent of land-use changes that took place in the northern half of the MCP from 1986 to 2019 and its efficacy, various Landsat satellite images that are freely available were processed, analysed and interpreted. The cloud-based Google Earth Engine (GEE) platform was used to determine the land-use changes. The random forest classification algorithm available within GEE was used to classify the Landsat 5 Thematic Mapper, Landsat 7 Enhanced Thematic Mapper Plus and Landsat 8 Operational Land Imager images for 1986, 1991, 1996, 2001, 2006, 2011, 2016 and 2019. The development of plantations was tracked, which indicated that forestry increased by more than $100 \%$ between 1986 and 2019. Over the same period, surface water bodies and wetlands decreased by $36.1 \%$ and $49.1 \%$, respectively. In addition to forestry, climate had a major impact on water resources in the MCP. Given that the MCP is a predominately groundwater-driven system, the impact of increased plantations on groundwater is an area that requires more investigation. This will improve the understanding of water resources in the area.

Conservation implications: The management, protection and conservation of water resources within protected areas are entwined with land-use decisions and planning outside of its boundaries. The rapid change in land-use experienced outside of protected areas and its impact on water resources disregard boundaries and may transgress on protected areas.

Keywords: Google Earth Engine; Landsat imageries; land-use change; remote sensing; northeastern South Africa; water resources; random forest classification; land cover.

\section{Introduction}

Changes in land use and land cover over time and space indicate socioeconomic change. Population growth and consequent demand for economic development have increased the conversion of natural vegetation. The KwaZulu-Natal Province has experienced an accumulated transformation of 45.6\% of natural vegetation between 1994 and 2008 (Jewitt 2012:12). One area that has been affected by land cover transformation is the Maputaland Coastal Plain (MCP) located in the north-east of the KwaZulu-Natal Province of South Africa, which is rich in biodiversity and other natural resources (Orimoloye et al. 2019:3). The MCP has several wetlands, lakes and game reserves, which play an integral role in maintaining a healthy ecosystem. The largest freshwater lake in South Africa, Lake Sibayi, and the iSimangaliso Wetland Park, which is a renowned Ramsar and World Heritage site, are located within the MCP (Weitz \& Demlie 2014:1). However, recent studies indicated that surface waters and wetland systems in the MCP are under severe threat because of plantations and water extraction (Everson et al. 2019:1; Orimoloye et al. 2019:9; Smithers et al. 2017:490). A large part of the Lake Sibayi catchment area is covered by plantations (Everson et al. 2019:34; Weitz \& Demlie 2014:1). Mbazwana and Manzegwena, the two largest plantations, cover approximately 8500 and 15000 ha, respectively, and were established in the 1960s by the KwaZulu Department of Forestry (SA Forestry 2012:1).

Pine plantations are deep-rooted, evergreen, non-native tree species that are known to extract soil water from below the root zone, limiting aquifer recharge and resulting in a lowered groundwater table (Kienzle \& Schulze 1992:1). As a result of this, the National Water Act (Act No. 36 of 1998) of South Africa considers plantations as a streamflow reduction activity, and as such, plantations require a water use license from the government. In coastal areas such as the $\mathrm{MCP}$, favourable solar radiation and air temperatures facilitate year-round growth and provide plantations the opportunity to access the shallow aquifers, resulting in higher water consumption than the surrounding natural vegetation (Everson et al. 2019:34). This has had a significant 
impact on surface water and wetland systems in the MCP as many of the surface water systems and wetlands in the MCP are predominately groundwater driven (Kelbe \& Germishuyse 2010:124).

Studies as early as the 1990s highlighted the negative impact that plantations had on the hydrology and ecology of the MCP. A study using aerial photography conducted by Rawlins (1991:30) indicated that the size and number of wetlands reduced as a result of the introduction of plantations in the area. Wetlands were reported to exist during the early growth stages of the plantations; however, these dried up as the plantations matured and were only visible for a short period after heavy rainfall (Rawlins 1991:30). Smithers et al. (2017:490) indicated that 35\% of the total decrease in the level of Lake Sibayi was a result of forest plantations surrounding the lake. Orimoloye et al. (2019:1) opined that a 38\% decrease in wetlands in the iSimangaliso Wetland Park between 1987 and 2017 was because of the impact of plantations. Everson et al. (2019:5-8) investigated the water use of plantations and agroforestry systems in the MCP and deduced that eucalyptus trees use more water in a day when compared with the indigenous vegetation. Modelling results from the study indicated that the removal of forest plantations from the Vasi area of the MCP will result in a 2-m increase in the groundwater table. Furthermore, a $40 \%$ increase in water yield was predicted if the plantations were to be removed from the immediate vicinity of wetlands and replaced by agroforestry.

Despite these limited and specific spatiotemporal studies, the long-term impacts of land-use change, including plantations on water resources and wetland systems in the MCP, are not yet well understood and documented. Although land cover information such as the Ezemvelo KwaZulu-Natal Wildlife (EKZNW) maps is available, they do not extend back beyond 2005. Thus, there is a need for regularly updated and long-term land-use data to improve the understanding of changes in the land surface and the impact on water resources including wetlands. Recently, the Google Earth Engine (GEE) platform has been increasingly used in conjunction with earth observation data in change detection studies (Google Earth Engine 2018). As the GEE platform is cloud based, it increases the efficiency of producing long-term records of data. A 40-year collection of Landsat earth observation data is available within the GEE platform, providing an opportunity to produce land-use data over a longer time frame.

Previous studies are limited in their temporal and spatial investigation of afforestation in the MCP. The availability of a long-term data set of afforestation for the MCP provides an opportunity to expand on the outcomes of short-term studies to gain a better understanding of the hydrology over time. This study aims to track the development of plantations over a 30-year period and its potential impacts on surface water and wetlands systems in the MCP using supervised classification.

\section{Description of the study area Location and climate}

The MCP is located in the north-eastern coastal plain of the KwaZulu-Natal Province, South Africa (Figure 1). The coastal plain extends from Mlalazi in the south to Mozambique in the north. The coastal plain is bounded by the Lebombo Mountains in the west and the Indian Ocean in the east. The present study focuses on the region stretching from the northern perimeter of the Mkhuze Swamp in the south to the South AfricaMozambique national boundary in the north (Figure 1). The MCP falls under the Usutu to Mhlatuze Water Management Area and has a population of approximately 573353 people (Statistics SA 2011). It is described as one of the most underdeveloped areas in South Africa as unemployment, access to piped water, lack of electricity and low education levels are prevalent in the region (Statistics SA 2011).

The climate of the study area is subtropical and receives summer rainfall, with a 30-year mean annual precipitation of approximately $580 \mathrm{~mm}$ (Figure 4) (SAWS 2018). The majority of the rainfall occurs during the summer months, between October and March, and is highly spatially and temporally variable. The rainfall decreases from the coast inland towards the Lebombo Mountains. Mean daily temperatures vary from $21.0^{\circ} \mathrm{C}$ to $32.1{ }^{\circ} \mathrm{C}$ in summer and $10.9{ }^{\circ} \mathrm{C}$ to $26.4{ }^{\circ} \mathrm{C}$ in winter (SAWS 2018). The mean potential evaporation rate for the study area is approximately $1458 \mathrm{~mm}$ year $^{-1}$ (DWS 2018).

\section{Topography, drainage and land cover}

The topography of MCP is generally flat. The highest elevation in the area is approximately $700 \mathrm{~m}$ above mean sea level and occurs along the Lebombo mountain range in the western boundary of the study area. From here, the elevation drops to sea level at the coast. The surface water bodies (lakes, rivers and wetlands) are predominately groundwater driven (Kelbe \& Germishuyse 2010:124). The main rivers that drain the MCP are the Umfolozi, Mhlathuze, Pongola and Mkuze rivers (Kelbe \& Germishuyse 2010:124). The Umfolozi River that once formed part of the St. Lucia wetland has since separated from the wetland. The Mhlathuze River flows into the Richards Bay harbour, and the Pongola River flows into Mozambique towards the Maputo Bay. The Mkuze River, along with the Nylazi, Hluhluwe and Mzinene rivers, flow into Lake St. Lucia (Kelbe \& Germishuyse 2010:124). Lake Sibayi and the Kosi Bay lake systems are the two main lakes in MCP (Figure 1). The study area forms part of the Maputaland-Pondoland-Albany Hotspot.

Indian Ocean Coastal Belt (IOCB), savanna and forest are the three biomes covering the study area. The IOCB runs along the coast and up to $20 \mathrm{~km}$ inland. It consists of the Maputaland Coastal Belt and Maputaland Wooded Grassland (Mucina \& Rutherford 2006:573). The central and western portions consist of vegetation forming the savanna biome. This includes the Maputaland Pallid Sandy Bushveld, Muzi Palm Veld and Wooded Grassland, Tembe Sandy Bushveld, Makatini Clay Thicket, Western Maputaland Sandy Bushveld 


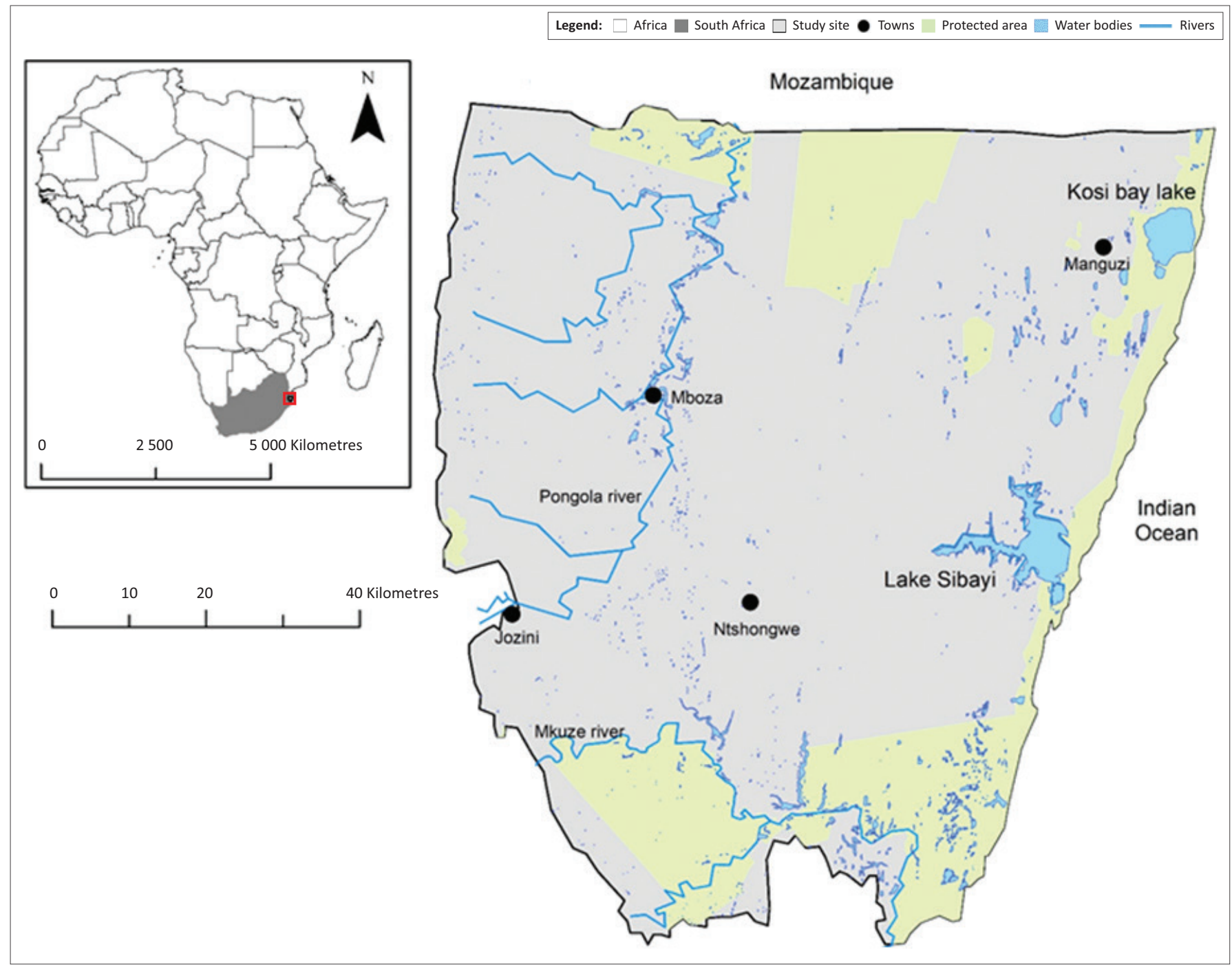

FIGURE 1: Location map of the study area in north-eastern South Africa.

and Southern Lebombo Bushveld, which cover the entire Lebombo mountain range (Mucina \& Rutherford 2006:573). The Sand Forest, the Lowveld Riverine Forest and the Northern Coastal Forest are distributed throughout the study area (Mucina \& Rutherford 2006:571). Adjacent to St. Lucia, the wetland type vegetation is evident through the azonal vegetation identified in SANBI (2018). Large areas of the IOCB and savanna biomes have been replaced by plantations and commercial agriculture, with homesteads distributed throughout the biome regions.

\section{Methods and material \\ Earth observation data and data processing}

The multi-year land-use maps reported in this study were produced using JavaScript in GEE Application Programming Interface. Google Earth Engine (GEE) is a cloud-based platform for earth science and data analyses (Google Earth Engine 2018). Google Earth Engine (GEE) contains a multipetabyte catalogue of over 40 years of satellite imagery and geospatial data sets with massive computational abilities available for users to perform studies relating to change detection, trend mapping and quantify changes on the Earth's surface (Google Earth Engine 2018).

Landsat 5 Thematic Mapper (TM), Landsat 7 Enhanced Thematic Mapper Plus (ETM+) and Landsat 8 Operational Land Imager (OLI) surface reflectance data were used. As the operational period for each satellite is different, a combination of three satellites was used. Landsat 5 TM was launched in March 1984 and decommissioned in June 2013. Landsat 7 ETM+ and Landsat 8 OLI were launched in April 1999 and February 2013, respectively, and are still operational (USGS 2018). All have the same $30-\mathrm{m}$ spatial resolution. The flow diagram (Figure 2) describes the process undertaken in GEE to classify the Landsat images. The Landsat collection was filtered to acquire one cloud-free image every 5 years from 1986 to the most recent 2019 cloud-free images. Moreover, a cloud-free Landsat image for 2018 was obtained and used to validate against the 2018 South African National Land-Cover (SANLC) map. All but one of the cloud-free images were available during the winter months. The aim of this study was to determine long-term trends in land use and land cover, not the seasonal variability. Thus, although it is 


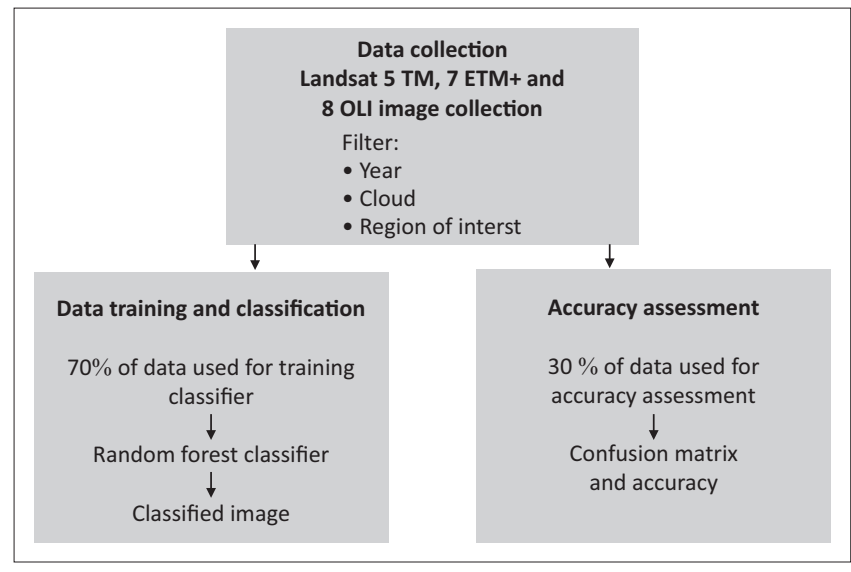

FIGURE 2: Flow chart summarising the methods followed.

acknowledged that in the wetland, lake levels will be lower in the dry, winter season, the consistency of using only winter images will allow the long-term changes to be identified. The images used in this study were for 04 November 1986, 23 July 1991, 18 June 1996, 16 June 2001, 14 June 2006, 23 August 2011, 12 August 2016, 15 June 2018 and 04 July 2019. The availability of images was limited because of cloud cover.

\section{Supervised classification}

Supervised classification is based on the premise that prior knowledge of the land classes in the study area is known (Richards \& Jia 2006:78). The users determine the land cover types to be investigated, and representative pixels for each type are identified. This is known as training, and the information is obtained either from field surveys, aerial photographs, maps, satellite imagery or a combination of these (Richards \& Jia 2006:80). Once the pixels are trained, a classifier is used to classify the rest of the image (Richards \& Jia 2006:298). Several classifiers are available, including the maximum likelihood, minimum likelihood, support vector machine and random forest.

\section{Training data}

Training data were obtained by visual inspection of TerraMetrics 15-m spatial resolution satellite imagery, the EKZNW land cover map and field data. Ezemvelo KwaZuluNatal Wildlife land cover map is a free data set available on request for 2005, 2008, 2011 and 2017. The EKZNW data sets were selected as they are well-recognised published maps for KwaZulu-Natal that have relatively high overall accuracies (Thompson 2018:21). The EKZNW land cover maps were produced using Sentinel 2 satellite imagery based on a 20-m spatial resolution (Thompson 2018:5). In addition to the use of the EKZNW maps, a field survey was conducted between 24 June 2019 and 28 June 2019, where a total of 65 in situ landuse data points were collected. The location of the data points was generated using a random point generator tool. The data points were collected around the study site and consist of 18 grasslands, 16 plantations, 14 indigenous vegetation, 7 wetlands, 5 urban, 4 bare ground and 1 agriculture data point. These data were used to assist in identifying land uses in the study area for training purposes.

Overall, 35 water body, 25 urban, 25 bare soil, 25 agriculture, 35 plantations, 50 grasslands, 50 natural vegetation, 30 wetlands and 30 degraded land reference polygons, accounting for over 70000 pixels, formed the reference data set, which was used to identify Landsat pixels that made up one of the nine land-use classes. The nine land-use classes were chosen as these were identified as the dominant land covers, which could be clearly distinguished for the study area. The nine land-use classes are water bodies, urban, bare ground, agriculture, plantations, grasslands, indigenous vegetation, wetlands and degraded land. Bare ground is described as a sand cover found typically on the coastline, whereas degraded land consisted of partial vegetation cover. From the reference data set, $70 \%$ of the sample data were randomly selected for training, and the remaining 30\% was used to validate the data set. The training data was used for the supervised classification algorithm, and the validation data were used in the accuracy assessment of the classified land-use maps.

\section{Image classification}

The random forest classification algorithm has become a popular model for land-use and land cover classification as it has produced more accurate results in comparison to other classification algorithms ( $\mathrm{Li}$ et al. 2014:21; Reynolds et al. 2016:2). The random forest classification is easier to operate, more efficient and robust to outliers and can handle a large amount of training data (Rodriguez-Galiano \& Chica-Rivas 2012:13). The random forest classifier has been used in several studies to map forests (Mellor et al. 2012; Senf, Hostert \& van der Linden 2012), wetlands (Berhane et al. 2018; Chignell et al. 2018), agriculture (Lebourgeois et al. 2017; Ok, Akar \& Gungor 2012) and land cover (Jin et al. 2018; Na et al. 2010). The random forest classifier consists of many decision trees that operate as an ensemble and requires two parameters to be identified to make accurate class predictions, namely, the number of predictor variables and the number of classification trees (Yiu 2019:1; Zurqania et al. 2018:178). Consequently, the random forest classification algorithm was adopted and used in GEE for this study.

\section{Accuracy assessment}

Accuracy assessment techniques are used to determine how well an image has been classified (NASA 2018:2). The validation data set was used to produce an error matrix for each of the classified images. The error matrix was used to determine the overall accuracy, kappa coefficient, user's accuracy and producer's accuracy using Equations 1, 2, 3 and 4 , respectively. The user's accuracy (error of commission) occurs when a pixel is incorrectly included in a category being evaluated, whereas the producer's accuracy (error of omission) occurs when a pixel is left out of the category being evaluated (NASA 2018:17). The kappa coefficient is a measure of inter-rater reliability and is used to determine the 
agreement between two data sets. The user's and producer's accuracies were generated for all nine classes for each image:

Overall accuracy $=\frac{\text { Sum of diagonal elements }}{\text { Total number of accurate pixels }}$

Kappa coefficient $(K)=\frac{P_{\text {agree- }} P_{\text {chance }}}{1-P_{\text {chance }}}$

where $P_{\text {agree }}$ is the agreement observed and $P_{\text {chance }}$ is the agreement expected by chance.

User's accuracy $=$

Total number of correct pixels in a category

Total number of pixels of that category derived

from the reference data (column total)

Total number of correct pixels

Producer's accuracy $=\frac{\text { in a category }}{\text { Total number of pixels of that category }}$ derived from the reference data (row total)

[Eqn4]

In addition to the error matrix, a land-use map was produced for 2018 and compared with the SANLC (2018) map. The SANLC map was chosen as it is a well-recognised published map for South Africa with an overall accuracy of $90.1 \%$. Classes from the SANLC (2018) map had to be merged to form classes that were comparable to the nine classes defined for this study. Open water bodies, such as rivers, estuaries, lakes, dams and natural pans, were merged to form the 'water' land cover. Residential areas including informal settlements, scattered and dense villages, commercial, industrial and roads were merged to form the 'urban' land cover. Natural rock, dry pans, coastal dunes and dry riverbeds were merged to form 'bare ground'. Cultivated commercial permanent orchards, cultivated commercial sugarcane (pivot and non-pivot), emerging farmer sugarcane non-pivot, commercial annual crops (irrigated and drylands) and subsistence farms were merged to form the 'agriculture' land cover. Contiguous and dense plantation forests, open and sparse plantation forests and temporary unplanted (clear-felled) plantation forests were merged to form 'plantations'. Natural grasslands were merged to form 'grasslands'. Contiguous (indigenous) forests, contiguous low forests and thicket, dense forests and woodland, open woodland and low shrubland were merged to form 'indigenous vegetation'. Herbaceous wetlands and mangrove wetlands were merged to form 'wetlands'.

\section{Ethical consideration}

The authors confirm that ethical clearance was not required for the study.

\section{Results}

The results obtained from the accuracy assessment, the comparison between the 2018 classified Landsat image and the SANLC (2018) map as well as the spatiotemporal changes for plantations, water bodies and wetlands from 1986 to 2019 are presented in this section.

\section{Accuracy assessment}

The overall accuracies achieved are all greater than $92 \%$ with the highest accuracy of $96.3 \%$ for the 1996 image (Table 1). The highest and lowest kappa coefficients are 0.95 (1996) and 0.89 (2011) (Table 1). The 2011 image was the only image based on the Landsat 7 ETM+ satellite data and has the lowest overall accuracies and kappa coefficient. This could be a result of scan lines present on the Landsat 7 ETM+ images.

The user's accuracy and producer's accuracy range from $60.2 \%$ to $99.9 \%$ and from $64.8 \%$ to $100 \%$, respectively (Table 1). Water bodies proved to be the most accurately predicted land-use class across all images with user's and producer's accuracies ranging between $99.7 \%$ and $99.9 \%$ and $99.7 \%$ and $100 \%$, respectively. The least accurately predicted class was the urban areas with a maximum user and producer accuracy of $72.3 \%$ and $76.5 \%$, respectively. A majority of the settlements in the study area are located within grasslands; as a result, some settlement areas, which should have been classed as urban land use, are classed as grasslands in the majority of the images classified. The plantation land-use class produced user's and producer's accuracies ranging from $71.6 \%$ to $92 \%$ and $72.0 \%$ to $91 \%$, respectively.

TABLE 1: The user's accuracy, producer's accuracy, overall accuracies and kappa coefficients for the classified Landsat images.

\begin{tabular}{|c|c|c|c|c|c|c|c|c|c|c|c|c|c|c|c|c|}
\hline \multirow[t]{2}{*}{ Landuse class } & \multicolumn{2}{|c|}{1986} & \multicolumn{2}{|c|}{1991} & \multicolumn{2}{|c|}{1996} & \multicolumn{2}{|c|}{2001} & \multicolumn{2}{|c|}{2006} & \multicolumn{2}{|c|}{2011} & \multicolumn{2}{|c|}{2016} & \multicolumn{2}{|c|}{2019} \\
\hline & UA (\%) & PA (\%) & UA (\%) & PA (\%) & UA (\%) & PA (\%) & UA (\%) & PA (\%) & UA (\%) & PA (\%) & UA (\%) & PA (\%) & UA (\%) & PA (\%) & UA (\%) & PA (\%) \\
\hline Water & 99.7 & 99.9 & 99.9 & 99.9 & 99.8 & 99.7 & 99.8 & 99.8 & 99.7 & 99.9 & 99.8 & 99.7 & 99.9 & 99.9 & 99.9 & 100.0 \\
\hline Urban & 71.8 & 73.1 & 71.6 & 69.7 & 65.6 & 69.8 & 70.2 & 69.1 & 72.3 & 76.5 & 64.0 & 64.9 & 66.8 & 70.9 & 60.2 & 64.8 \\
\hline Bare ground & 99.8 & 98.4 & 98.8 & 96.6 & 98.1 & 96.2 & 98.9 & 98.9 & 96.7 & 96.5 & 97.4 & 97.8 & 96.4 & 97.3 & 95.4 & 98.0 \\
\hline Agric & 93.1 & 91.0 & 89.4 & 89.9 & 74.5 & 80.1 & 84.2 & 83.5 & 86.3 & 87.7 & 82.2 & 83.7 & 83.4 & 86.2 & 85.5 & 85.7 \\
\hline Plantations & 88.5 & 90.0 & 90.3 & 91.0 & 92.0 & 89.4 & 86.5 & 85.5 & 86.7 & 87.5 & 71.6 & 72.0 & 83.9 & 83.7 & 81.5 & 82.4 \\
\hline Indigenous veg & 97.9 & 98.0 & 98.2 & 98.3 & 98.5 & 98.4 & 98.5 & 98.7 & 98.1 & 98.1 & 95.9 & 96.1 & 97.1 & 97.1 & 97.1 & 97.1 \\
\hline Wetlands & 94.0 & 93.2 & 95.3 & 95.5 & 96.2 & 96.9 & 96.9 & 96.5 & 96.0 & 96.6 & 88.3 & 87.8 & 93.2 & 92.2 & 92.2 & 92.6 \\
\hline Degraded land & 92.4 & 92.0 & 92.0 & 92.5 & 93.5 & 93.1 & 88.9 & 89.2 & 93.2 & 93.4 & 88.9 & 88.2 & 90.6 & 90.3 & 87.9 & 87.5 \\
\hline Overall accuracy (\%) & - & 95.5 & - & 96.0 & - & 96.3 & - & 95.4 & - & 96.0 & - & 92.3 & - & 94.0 & - & 93.5 \\
\hline Kappa coefficient & - & 0.9 & - & 0.9 & - & 0.9 & - & 0.9 & - & 0.9 & - & 0.9 & - & 0.9 & - & 0.9 \\
\hline
\end{tabular}

UA, user's accuracy; PA, producer's accuracy. 


\section{Validation of the $\mathbf{2 0 1 8}$ Landsat classified map}

The 2018 Landsat classified land-use map was compared with the 2018 SANLC map (2018) as part of the validation study. The water bodies, wetlands and plantations land-use classes were compared.

The regression indicates a good correlation between the two data sets with a coefficient of determination $\left(R^{2}\right)$ of 0.92 . Water bodies have the least difference in area between the two maps followed by wetlands and plantations. Water bodies covered a total area of 10303 ha according to the SANLC (2018) map, whereas the Landsat classified map had a total area of 11260 ha (Table 2). The Landsat classified map overestimated water bodies, wetlands and plantations by approximately $9.3 \%, 4.4 \%$ and $29.3 \%$, respectively. These small discrepancies may be attributed to the fact that the SANLC (2018) map was produced at a 20-m spatial resolution compared with the Landsat image, which has a 30-m spatial resolution.

\section{Land-use changes in the Maputaland Coastal Plain from 1986 to 2019}

Plantations, water bodies and wetland land-use classes from 1986 to 2019 were selected and assessed. Most of the plantations are located along the coastline, just north and south of Lake Sibayi (Figure 3). Plantations increased at an average rate of 235 ha year ${ }^{-1}$ between 1986 and 1991, which increased to approximately 2372 ha year-1 by 2019 (Table 3). This indicates that the rate of change increased 10-fold between 1986 and 2019. The plantation coverage increased by about 22549 ha between 1986 and 2019. Initially, the plantation was concentrated around Lake Sibayi. Between 1986 and 2001, a 5936-ha increase in plantations was observed. This expansion of plantation occurred in the region north of Lake Sibayi with smaller plantations developing west of Lake Kosi Bay. In 2006, there was a decrease in forestry, possibly because of felling. Following this, a 35.4\% (11 193 ha) increase in plantations occurred between 2006 and 2019. The classified images between 2006 and 2019 (Figure 3) indicate that the expansion of commercial plantations was concentrated in the area west of Kosi Bay and to a smaller extent west of Lake Sibayi.

Surface water bodies and wetlands have experienced a decline since 1986. The largest rate of change was experienced during the 2001-2006 period for surface water bodies with an average decrease of 444 ha year ${ }^{-1}$. During the same period, wetlands experienced the largest rate of decline of 1383 ha year $^{-1}$ (Table 3). Open water bodies decreased by $17.5 \%$ between 1986 and 1996 (Figure 4). However, water bodies increased by $0.5 \%$ between 1996 and 2001. From 2001 to 2019, a more significant decrease by $22.9 \%$ was observed. An overall decrease of 36.1\% occurred between 1986 and 2019. The largest rate of change was experienced during the 2001-2006 period with an average decrease of 444 ha year-1 (Table 3). The extent of Lake Sibayi and water bodies located in the middle of the study area visibly declined in the images from 1986 to 2019 (Figure 3). Between 2001 and 2006, the southern basin of Lake Sibayi became noticeably smaller (Figure 3). By 2016, the southern portion of the lake was disconnected from the main lake and continued to decrease, as can be seen in the 2019 image (Figure 3). The water bodies located near the middle of the study area have also decreased between 1986 and 2019 and, in some instances, disappeared. The water bodies in the Kosi Bay area do not seem to have been affected that much. Within the conservation area, water bodies decreased by $17.5 \%$ between 1986 and 2019 .

The distribution of wetlands located in the study area is shown in the classified images of Figure 3, where the most extensive one is located in the southern section of the study area. The extent of wetlands is visibly smaller in the 1986 image as a result of below-average rainfall received in 1985 (DWS 2018). Between 1986 and 1991, a 16.7\% increase in wetlands occurred (Figure 4), particularly along and around water bodies in the northern region of the study area and in the south-west section of the study area (Figure 3).

The extent of wetlands remained relatively constant with a 705.7-ha difference between 1996 and 2001. The extent began to decrease significantly from 2001 onwards (Figure 4). Between 2001 and 2019, wetlands decreased by $47.9 \%$. The highest rate of wetland decline was experienced during the 2001 and 2006 period at a rate of 1383 ha year ${ }^{-1}$ (Table 3). A decrease in the extent of the iSimangaliso wetland in the south and wetlands located on the northern boundary of the study area is noticeable in the classified maps. Generally, wetlands experienced an overall decrease of 15862.6 ha (49.1\%) during the study period. Wetlands within the conservation area increased between 1986 and 1996, and after which, their extent decreased by an overall $18 \%$.

Urban areas increased by 36.5\% between 1986 and 1996 (Figure 4). This was followed by a decrease of $4.8 \%$ between 1996 and 2001. Overall, the urban land class increased by $38 \%$ between 1986 and 2019.

\section{Discussion}

\section{Image processing, classification and validation}

The random forest classification algorithm was used within the GEE platform to produce land-use maps for the northern

TABLE 2: Area comparison between South African National Land-Cover map (2018) land cover and the Landsat 2018 classified map.

\begin{tabular}{lcccc}
\hline Land use class & SANLC 2018 (ha) & Landsat classified map for 2018 (ha) & Area difference (ha) & Percentage difference (\%) \\
\hline Water bodies & 10303 & 11260 & 957 & 9.3 \\
Wetlands & 27918 & 29139 & 1221 & 4.4 \\
Plantations & 26106 & 33751 & 7645 \\
\hline
\end{tabular}

SANLC, South African National Land-Cover. 
MCP for the years 1986, 1991, 1996, 2001, 2006, 2016 and 2019 to assess long-term trends and changes. The results of the validation study indicate a good overall goodness of fit $\left(R^{2}=\right.$ 0.92). The overall accuracy ranged between $92.3 \%$ and $96.3 \%$. The 2011 image had the lowest overall accuracy (92.3\%) because of the gap-filled scan lines present in the Landsat 7 ETM+ image, which may have affected the accuracy of the classification. The Landsat 7 ETM+ 2011 image was used as there was no cloud-free image available from Landsat 5 . The overall accuracy decreased from 1986 to 2019. This could be zattributed to the change in land cover over time. As land cover heterogeneity increases, the probability of misclassifying pixels increases, which influences the overall accuracy (Smith et al. 2002:69).

The error matrix for all eight images indicated that urban areas were the least accurate land cover class predicted. The reason for the poor estimation of the urban land cover class could be attributed to the 30-m spatial resolution of the Landsat satellite data, which failed to capture the homesteads in the MCP, as many of them are smaller than the satellite resolution. Furthermore, the yards are not tarred or paved and are covered by grass or shrub vegetation and small subsistence vegetable plots, which may have been incorrectly

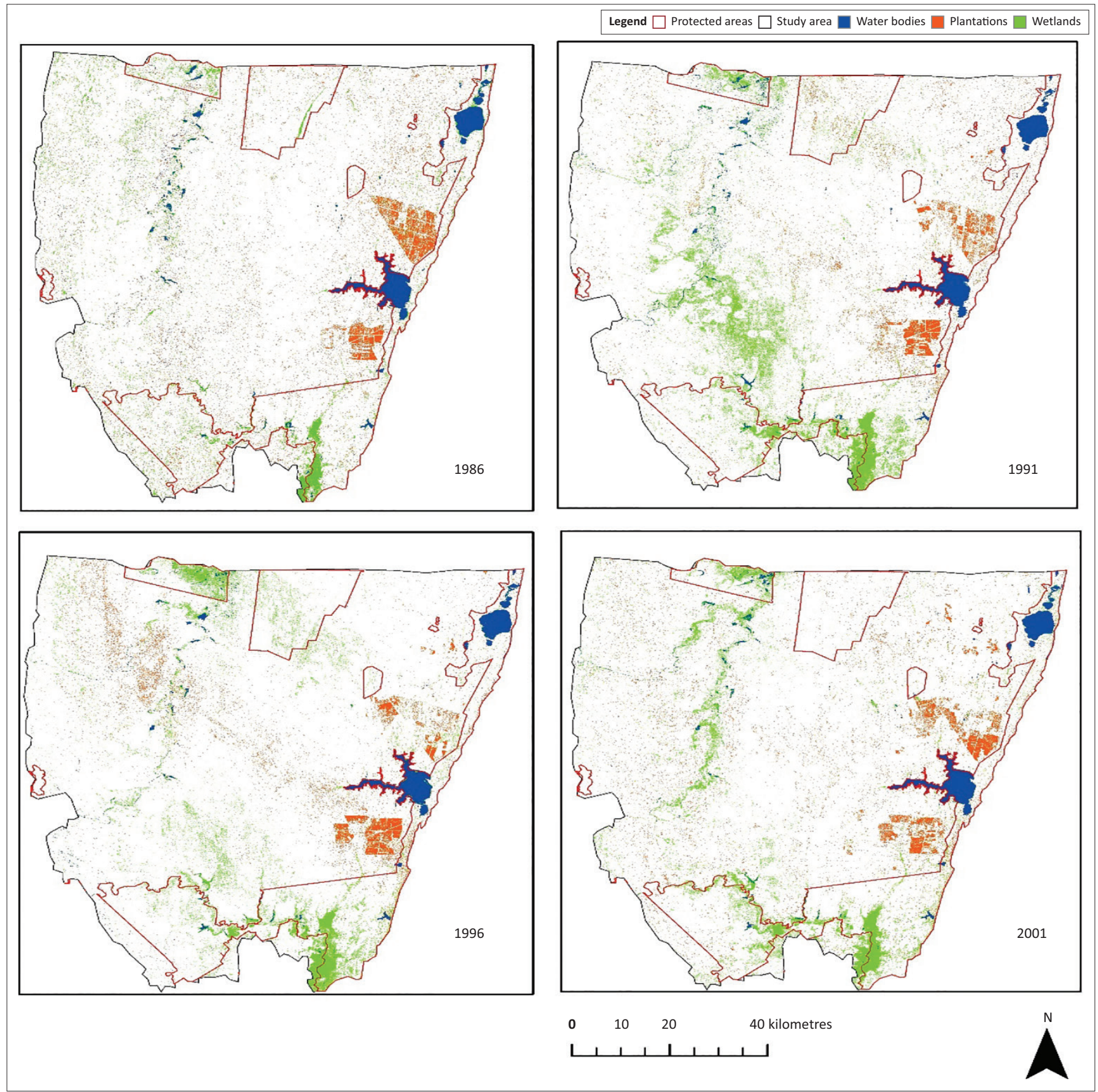

FIGURE 3: Spatial distribution of forests, water bodies and wetlands for the Maputaland Coastal Plain between 1986 and 2019. 


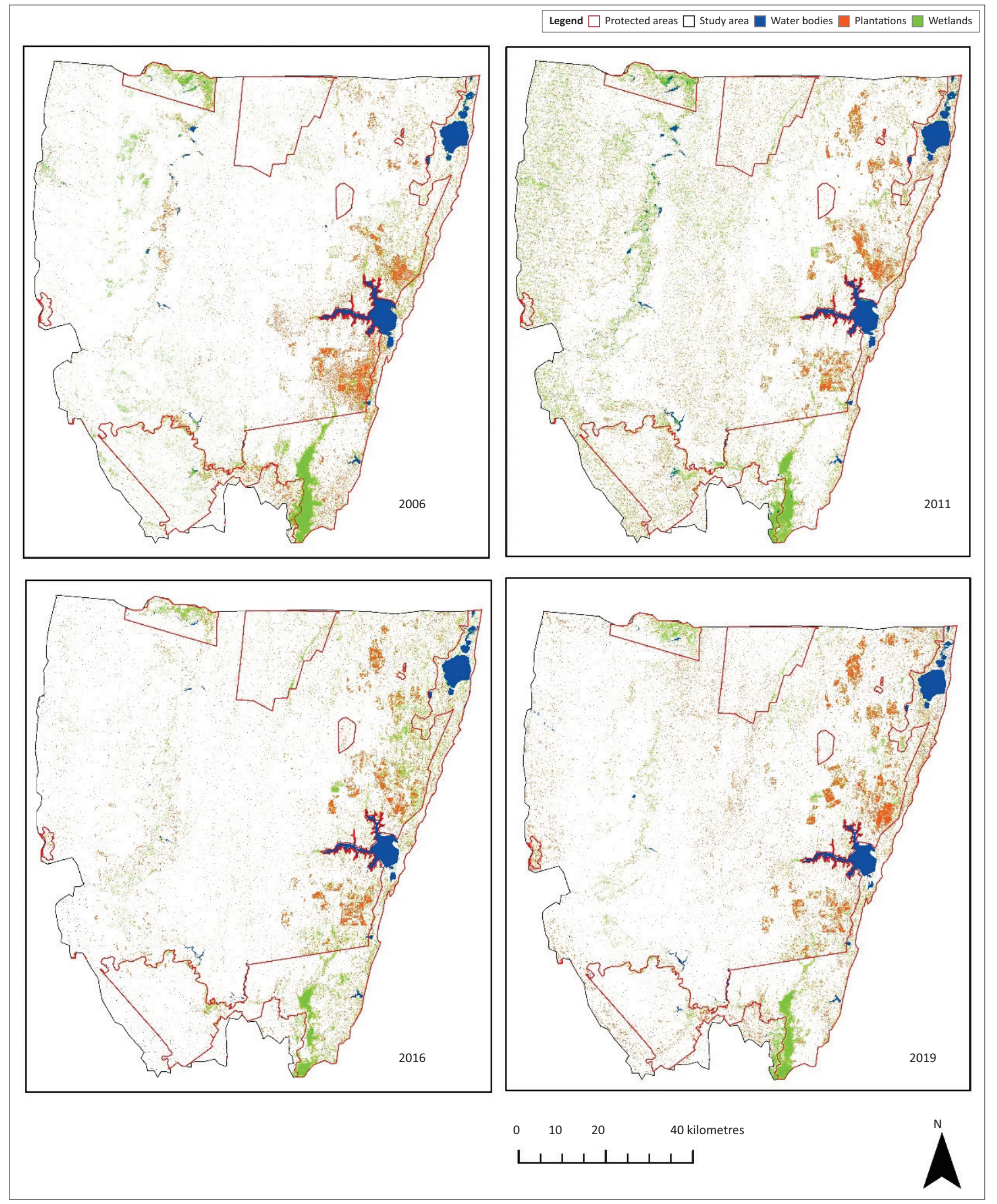

FIGURE 3 (Continues...): Spatial distribution of forests, water bodies and wetlands for the Maputaland Coastal Plain between 1986 and 2019.

mapped as grassland land cover. Improved classification of urban areas can be achieved using a finer resolution satellite such as Sentinel (10 $\mathrm{m}$ resolution); however, imagery is not available for long-term studies. The lower accuracies achieved for the grasslands, plantation and agricultural classes may be attributed to the random forest classification algorithm. Jin et al. (2018:17) identified Normalized Difference Vegetation Index (NDVI) as the most important 
TABLE 3: Net area change (ha year ${ }^{-1}$ ) between measurement periods for plantations, surface water bodies and wetlands.

\begin{tabular}{lcccccccc}
\hline Land use class & $\mathbf{1 9 8 6 - 1 9 9 1}$ & $\mathbf{1 9 9 1 - 1 9 9 6}$ & $\mathbf{1 9 9 6 - 2 0 0 1}$ & $\mathbf{2 0 0 1 - 2 0 0 6}$ & $\mathbf{2 0 0 6 - 2 0 1 1}$ & $\mathbf{2 0 1 1 - 2 0 1 6}$ & $\mathbf{2 0 1 6 - 2 0 1 9}$ & $\mathbf{1 9 8 6 - 2 0 1 9}$ \\
\hline Plantations & 235 & 151 & 801 & 1084 & -1231 & 1098 & 2372 & 683.2909 \\
Surface water bodies & -242 & -316 & 12 & -444 & -56 & -132 & -174.325 \\
Wetlands & 1078 & -1085 & -141 & -1383 & -623 & -497 & -523 \\
\hline
\end{tabular}

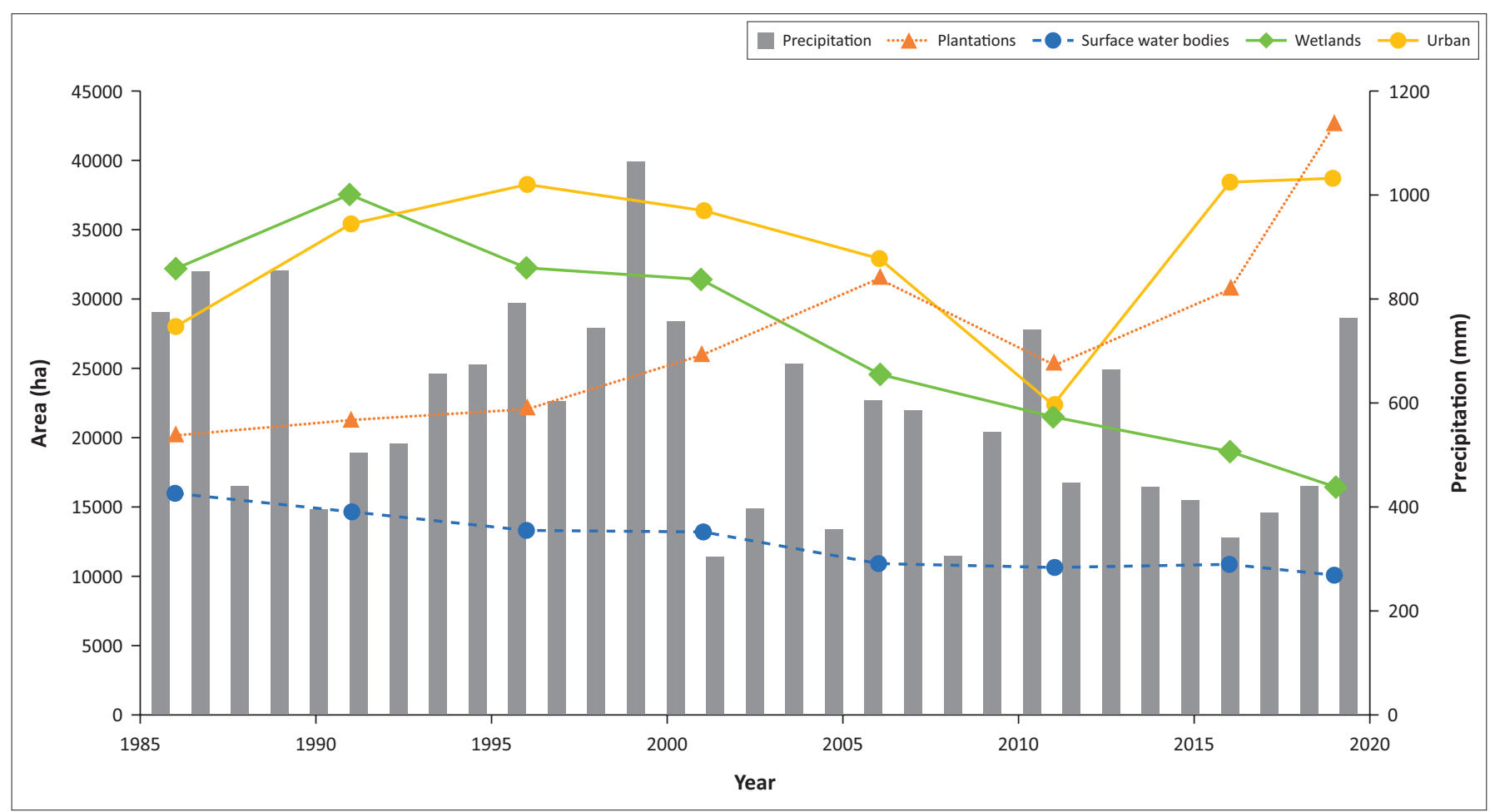

FIGURE 4: Change in area covered by plantations, water bodies and wetlands, as well as annual precipitation for the study area, for the period from 1986 to 2019.

variable that influenced the random forest classifier. The limited availability of water, particularly in recent years, may have influenced the NDVI of grasslands, plantations and rainfed agriculture lands during the winter season and hence affected the results achieved. The 30-m spatial resolution appeared to be suitable for water bodies and wetlands as the overall accuracies for these classes were relatively high.

\section{Land-use/land cover change}

The Landsat classified maps from 1986 to 2019 indicated an overall increase in size and number of plantations, wherein it more than doubled during the last three decades. The Manzengwenya and Mbazwana plantations have expanded but most notable was the development of new plantations near the Kosi Bay area and west of Lake Sibayi. These findings were in line with earlier reports by Weitz and Demlie (2014:1) and Everson et al. (2019:69), who expressed concern that plantations in the MCP were increasing. The new plantation developments are visibly smaller than the Manzengwenya and Mbazwana plantations and are likely related to smallscale woodlots grown by subsistence farmers. SA Forestry (2012:1) reported that Mondi, a timber production company, has been assisting the local communities that are located from Sodwana Bay to the Mozambique border in establishing small-scale commercial plantations as means of livelihoods. Another timber production company, Sappi, has established a programme that provided small-scale growers with a minimum of 5 ha (SA Forestry 2012:1). One such site is established near Manguzi, near Lake Kosi Bay (Sappi 2020:1). Many studies highlighted the high water use of plantations compared with the natural vegetation it replaces (Dye 1996:33; Dye \& Versfeld 2007:122; Everson et al. 2019:6). The evergreen canopies, high leaf area index and deep roots coupled with favourable climatic conditions are the drivers behind the high water use of plantations (Dye \& Versfeld 2007:122; Everson et al. 2019:138). The deep root systems of plantations allow the trees to access groundwater, which is not accessible by shallow-rooted grasslands and poses a threat to groundwater systems. Water use of Pinus plantations from three summerrainfall catchments in South Africa, namely, Cathedral Peak, Mokobulaan A and Mokobulaan B, ranged between 750 and 900 mm year ${ }^{-1}$ (Dye 1996:32). Recently, Everson et al. (2019:5) estimated the average daily water use of individual trees in the MCP. Small Eucalyptus trees had an average daily water use of $19.2 \mathrm{~L}^{\text {day }}{ }^{-1}$, whereas the average daily water use of mature trees was 8.0 and $11.41 \mathrm{Lday}^{-1}$ for Pinus and Eucalyptus, respectively. In Nebraska Sand Hill, United States, Adane et al. (2018:180) reported that annual average groundwater recharge rates decreased from 9.65 to $0.07 \mathrm{~cm}_{\text {year }}{ }^{-1}$ when natural grasslands were replaced with Pinus plantations. Ndlovu and Demlie (2018:1) reported that groundwater level around the Tembe and Mbazwana areas in MCP decreased by $0.7 \mathrm{~m}$ and $2.7 \mathrm{~m}$, respectively. 
The Landsat classified maps revealed a decrease in water bodies and wetlands in the study area during the same period. The main drivers for the reduction in the extent of open water bodies and wetland systems are the expansion of plantations and the change in climate. The results of this study are consistent with the findings of Rawlins (1991:30) and Smithers et al. (2017:490), where plantations are reported to have induced a reduction in the extent of surface water and wetland systems. Since the early 1990s, studies have indicated that plantations have reduced the size and number of wetlands in the MCP (Rawlins 1991:30). Rawlins (1991:30), Everson et al. (2019:24) and Orimoloye et al. (2019:1) noted the reduction in wetlands linked to plantations, with Orimoloye et al. (2019:1) finding a 38\% decrease in wetlands in the iSimangaliso Wetland Park between 1987 and 2017. Moreover, Grundling, Van Den Beg \& Price (2013:135) reported that wetlands in the MCP decreased as a result of land-use change and drought.

The present study found an overall decrease of $49.1 \%$ in wetlands that is far more than that reported by Orimoloye et al. (2019), which is related to the difference in the size of the study area investigated and the length of time considered. Smithers et al. (2017:490) indicated that plantations were the cause of a 35\% drop in the water level of Lake Sibayi and that removal of the forest from the catchment area would increase water yield substantially. Elsewhere in the world, D'Amato et al. (2017:270) stated that plantations in southern China had negative impacts on water quantity and suggested the removal of plantations to improve water availability. Immediate increase in water yield following the removal of plantations has been reported in many countries, including south-eastern Australia (Bren \& Hopmans 2007:1), India (Sikka et al. 2003:1) and several Andean countries (Bonnesoeur et al. 2019:575). Similarly, Woodward et al. (2014:1) reported that the removal of forests has increased the water available to wetlands and, in some instances, created new wetlands, particularly in Australia and New Zealand.

Climate has a major impact on water resources in the MCP. Pitman and Hutchison (1975) highlighted that Lake Sibayi was highly sensitive to changes in local climate. In addition to forestry, the decrease in the extent of water bodies reported in this study for the period between 1991 and 1996 may be attributed to a severe drought that occurred between 1992 and 1995 (Kelbe \& Germishuyse 2010:183; Ndlovu \& Demlie 2020:8). Rainfall data from the Makatini Research Centre (Figure 4) recorded an average annual precipitation of 471 mm between 1992 and 1994. This was lower than the 30-year average annual precipitation of $580 \mathrm{~mm}$ between 1988 and 2018. The increase in water bodies found between 1996 and 2001 is attributed to the higher rainfall the area received during the same period, where surface water bodies increased in area by approximately 12 ha year ${ }^{-1}$. However, the following decade recorded lower-than-average rainfall, which was a major contributor to the shrinkage of wetlands and lake level reduction reported for the study area (Nsubuga, Mearns \& Adeola 2018:1; Smithers et al. 2017:490). Climatic patterns investigated over the study period found that below-average rainfall has been experienced in the study area since 2001 (Blamey et al. 2018:6). Nsubuga et al. (2018) analysed rainfall data from eight stations in the MCP and reported a strong correlation $(0.88)$ between precipitation and surface water levels. The study reported in this article shows that, the extent of surface water bodies decreased by about 444 ha year-1 $^{-1}$ between 2001 and 2006; this decrease was consistent with that reported in Smithers et al. (2017:490) and Nsubuga et al. (2018:1).

\section{Implications on conservation areas}

This study showed that expansion of plantations and decrease in rainfall in the MCP have resulted in a decrease in the extent of surface water bodies and wetlands. The expansion of plantations is concentrated around the southnorth axis of the recharge area of the iSimangaliso Wetland Park. Consequently, the extent of water bodies and wetlands in the conservation areas of the MCP decreased by $17 \%$ and $24 \%$, respectively. Because of the interconnected nature of the hydrologic system of the MCP, any stress on the groundwater systems will transmit automatically into surface water bodies and wetlands, including the conservation areas. This suggests that land-use planning and decisions outside of conservation areas and their impact on water resources disregard boundaries and may transgress on conservation areas.

\section{Conclusion}

The north-eastern MCP has undergone significant change in land use over the last five decades, including afforestation, agriculture and rural settlements. To understand and map these land-use changes, the cloud-based GEE platform was used to process and classify satellite data for the period from 1986 to 2019 . The random forest classifier was used to classify a total of eight images for the study period. The overall accuracies of the classification achieved range from a minimum of $92.3 \%$ (2011) to a maximum of $96.3 \%$ (1996). The spatial expansion of plantations is clearly indicated, and an inverse relationship with surface water bodies and wetlands is noticed over the study period.

The development of plantations was tracked between 1986 and 2019, which indicated that during the last decade, the rate of development has increased. The Landsat classified images indicated that the expansion of plantation was concentrated in the area west of Lake Kosi Bay and Lake Sibayi. Over the same period, surface water bodies and wetlands decreased by $36.1 \%$ and $49.1 \%$, respectively. As a result of the shrinkage in the areal extent of the lakes, the southern basin of Lake Sibayi was disconnected from the main basin of the lake in 2016, and the lake area continued to decrease. Water bodies located around the middle of the study area have also been negatively affected, and some of them have disappeared in the 2019 classified map. Similarly, the extent of wetlands decreased significantly, and a $47.9 \%$ reduction in area was noted between 2001 and 2019. The decrease in the extent of surface water systems, including lakes and wetlands, is not only attributed to land-use changes 
such as the expansion of plantation but also to climate changes in the form of below-average rainfall.

This study confirms that the GEE platform is an ideal tool for processing earth observation data at large spatial and longtime scales as it contains a multi-petabyte catalogue of satellite imagery and geospatial data sets with massive computational abilities, which allow users to efficiently determine long-term land-use changes for large areas. The results of the multi-temporal land-use and land cover information reported in this article will undoubtedly inform policy- and decision-making related to the impacts of landuse change, including critical evaluation of water use license issues related to various scales of plantations and undertaking consistent compliance monitoring.

\section{Acknowledgements}

The South African Weather Service is acknowledged for the meteorological data; Dr. Gokool of the University of KwaZulu-Natal, for assisting in the use of Google Earth Engine; Ezemvelo KwaZulu-Natal Wildlife, for providing the land-use maps, and the South African National Biodiversity Institute, for providing the South African National Land-Cover map.

\section{Competing interests}

The authors declare that they have no financial or personal relationships that may have inappropriately influenced them in writing this article.

\section{Authors' contributions}

M.R., M.D., M.L.T. and S.J.v.R. contributed to the design and implementation of the research, analysis of the results and writing of the manuscript.

\section{Funding information}

The financial assistance of the Expanded Freshwater and Terrestrial Environmental Observation Network, hosted by the National Research Foundation's South African Environmental Observation Network business unit, and the South African Department of Science and Innovation towards this research is acknowledged.

\section{Data availability statement}

The data that support the findings of this study are available from the corresponding author (M.R.) upon reasonable request.

\section{Disclaimer}

Opinions expressed and conclusions arrived at in this article are those of the authors and are not necessarily to be attributed to the National Research Foundation or the South African Environmental Observation Network.

\section{References}

Adane, Z.A., Nasta, P., Zlotnik, V. \& Wedin, D., 2018, 'Impact of grassland conversion to forest on groundwater recharge in the Nebraska Sand Hills', Journal of Hydrology: Regional Studies 15, 171-183. https://doi.org/10.1016/j.ejrh.2018.01.001

Berhane, T.M., Lane, C.R., Wu, Q., Autrey, B.C., Anenkhonov O.A., Chepinoga V.V. \& Liu, H., 2018, 'Decision-tree, rule-based, and random forest classification of highresolution multispectral imagery for wetland mapping and inventory', Remote Sensing 10(580), 1-26. https://doi.org/10.3390/rs10040580

Blamey, R.C., Kolusu, S.R., Mahlalela, P., Todd, M.C. \& Reason, C.J.C., 2018, 'The role of regional circulation features in regulating El Niño climate impacts over southern Africa: A comparison of the 2015/2016 drought with previous events' International Journal of Climatology 38(11), 4276-4295. https://doi.org/10.1002/ Internationd
joc.5668

Bonnesoeur, V., Locatelli, B., Guariguata, M.R., Ochoa-Tocachi, B.F., Vanacker, V., Mao, Z., Stokes, A. \& Mathez-Stiefel, S., 2019, 'Impacts of forests and forestation on hydrological services in the Andes: A systematic review', Forest Ecology and Management 433, 569-584. https://doi.org/10.1016/j.foreco.2018.11.033

Bren, L. \& Hopmans, P., 2007, 'Paired catchments observations on the water yield of mature eucalypt and immature radiata pine plantations in Victoria, Australia', Journal of Hydrology 336(3), 416-429. https://doi.org/10.1016/j. jhydrol.2007.01.018

Chignell, S.M., Luizza, W.M., Skach, S., Young, N.E. \& Evangelista, P.H., 2018, 'An integrative modeling approach to mapping wetlands and riparian areas in a heterogeneous rocky mountain watershed', Remote Sensing in Ecology and Conservation 4(2), 150-165. https://doi.org/10.1002/rse2.63

D'Amato, D., Rekola, M., Wan, M. \& Cai, D., 2017, 'Effects of industrial plantations on ecosystem services and livelihoods: Perspectives of rural communities in China', Land Use Policy 63, 266-278. https://doi.org/10.1016/j.landusepol.2017.01.044

Department of Water and Sanitation (DWS), 2018, Daily evaporation data.

Dye, P., 1996, 'Climate, forest and streamflow relationships in South African afforested catchments', Commonwealth Forestry Association 75(1), 31-38.

Dye, P. \& Versfeld, D., 2007, 'Managing the hydrological impacts of South African plantation forests: An overview', Forest Ecology and Management 251(1-2), 121-128. https://doi.org/10.1016/j.foreco.2007.06.013

Everson, C.S., Scott-Shaw, B.C., Kelbe, B.E., Starke, A., Pearton, T., Geldenhuys, C. Vather, T. \& Maguire M., 2019, 'Quantifying the water-use of dominant land uses in the Maputaland Coastal Plain', in Water Research Commission Report No. TT 781/18. Pretoria, South Africa.

Google Earth Engine, 2018, Meet earth engine, viewed 01 November 2019, from https://earthengine.google.com/.

Grundling, A.T., Van Den Berg, E.C. \& Price, J.S., 2013, 'Assessing the distribution of wetlands over wet and dry periods and land-use change on the Maputaland Coastal Plain, north eastern KwaZulu-Natal, South Africa', South African Journal of Geomatics 2(2), 1-20.

Jewitt, D., 2012, 'Land cover change in KwaZulu-Natal', Environment Science and Policy for Sustainable Development 10, 12-13.

Jin, Y., Liu, X., Chen, Y. \& Lang, X., 2018, 'Land-cover mapping using random forest classification and incorporating NDVI time-series and texture: A case study of central Shandong', International Journal of Remote Sensing 39(23), 1-12. https:// doi.org/10.1080/01431161.2018.1490976

Kelbe, B. \& Germishuyse, T., 2010, 'Groundwater/surface water relationships with specific reference to Maputaland', in Water Research Commission Report No. $1168 / 1 / 10$. Pretoria, South Africa.

Kienzle, S.W. \& Schulze, R.E., 1992, 'A simulation model to assess the effect of afforestation on ground-water resources in deep sandy soils', Water SA 18(4), 265-272.

Lebourgeois, V., Dupuy, S., Vintrou, E. \& Ameline, M., 2017, 'A combined random forest and OBIA classification scheme for mapping smallholder agriculture at different nomenclature levels using multisource data (Simulated Sentinel-2 time series, VHRS and DEM)', Remote Sensing 9(259), 1-21. https://doi.org/10.3390/ rs9030259

Li, C., Wang, J., Wang, L., Hu, L. \& Gong, P., 2014, 'Comparison of classification algorithms and training sample sizes in urban land classification with Landsat Thematic Mapper Imagery', Remote Sensing 6(2), 964-983. https://doi. org/10.3390/rs6020964

Mellor, A., Haywood, A., Jones, A. \& Wilkes, P., 2012, 'Forest classification using random forests with multisource remote sensing and ancillary GIS data', in 16th Australasian remote sensing and photogrammetry conference proceedings, January 2012, pp. 40-44, Melbourne.

Mucina, L. \& Rutherford, M.C., 2006, The vegetation of South Africa, Lesotho and Swaziland, Strelitzia 19, South African National Biodiversity Institute, Pretoria.

Na, X., Zhang, S., Li, X., Yu, H. \& Liu, C., 2010, 'Improved land cover mapping using random forests combined with Landsat thematic mapper imagery and ancillary geographic data', Photogrammetric Engineering \& Remote Sensing 76(7), 833-84. https://doi.org/10.14358/PERS.76.7.833

NASA, 2018, 'Advanced webinar: Accuracy assessment of a landcover classification', in Remote sensing training program, February 13-20, 2018, pp. 1-20.

National Water Act (NWA), 1998, Act no. 36 of 1998, Government Printer, Pretoria. 
Ndlovu, M.S. \& Demlie, M., 2018, 'Statistical analysis of groundwater level variability across KwaZulu-Natal Province, South Africa', Journal of Environmental Earth Science 77(739), 1-15. https://doi.org/10.1007/s12665-018-7929-x

Ndlovu, M.S. \& Demlie, M., 2020, 'Assessment of meteorological drought and wet conditions using two drought indices across KwaZulu-Natal Province, South Africa', Atmosphere 11(623), 1-20. https://doi.org/10.3390/atmos11060623

Nsubuga, F.N.W., Mearns, K.F. \& Adeola, A.M., 2017, 'Lake Sibayi variations in response to climate variability in northern KwaZulu-Natal, South Africa' Theoretical and Applied Climatology 137, 1233-1245. https://doi.org/10.1007/ s00704-018-2640-0

Ok, A., Akar, O. \& Gungor, O., 2012, 'Evaluation of random forest method for agricultural crop classification', European Journal of Remote Sensing 45(3), 421-432. https://doi.org/10.5721/EuJRS20124535

Orimoloye, I.R., Mazinyo, S.P., Kalumba, A.M., Nel, W., Adigun, A.I. \& Ololade, O.O., 2019, 'Wetland shift monitoring using remote sensing and GIS techniques: Landscape dynamics and its implications on Isimangaliso Wetland Park, South Africa', Earth Science Informatics 12, 553-563. https://doi.org/10.1007/s12145019-00400-4

Pitman, W.V. \& Hutchison, I.P.G., 1975, 'A preliminary hydrological study of Lake Sibaya', in Hydrological Research Unit, Report 4/75, pp. 35. University of the Witwatersrand, Johannesburg.

Rawlins, B.K., 1991, 'A geohydrological assessment of the behaviour and response of the Zululand coastal plain to both environmental influences and human activity' Unpublished MSc, University of Zululand, Richards Bay.

Reynolds, J., Wesson, K., Desbiez, A.L.J., Ochoa-Quintero, J.M. \& Leimgruber, P., 2016 'Using remote sensing and random forest to assess the conservation status of critical cerrado habitats in Mato Grosso do Sul, Brazil', Land 5(12), 1-12. https:// doi.org/10.3390/land5020012

Richards, J.A. \& Jia, X., 2006, Remote sensing digital image analysis: An introduction, Springer, Heidelberg.

Rodriguez-Galiano, V.F. \& Chica-Rivas. M., 2012, 'Evaluation of different machine learning methods for land cover mapping of a Mediterranean area using multiseasonal Landsat images and Digital Terrain Models', International Journal of Digital Earth 7(6), 492-509. https://doi.org/10.1080/17538947.2012.748848

SA Forestry, 2012, SA's biggest land reform forestry project, viewed 29 January 2020, from http://saforestryonline.co.za/articles/land_and_community/sas_biggest land_reform_forestry_project/.

Sappi, 2020, Sappi Khulisa, viewed 09 August 2020, from https://www.sappi.com/ sappi-khulisa.
Senf, C., Hostert, P. \& van der Linden, S., 2012, 'Using MODIS time series and random forest classification for mapping land use in South-East Asia', in International Geoscience and Remote Sensing Symposium (IGARSS), Munich.

Sikka, A.K., Samra, J.S., Sharda, V.N., Samraj, P. \& Lakshmanan, V., 2003, 'Low flow and high flow responses to converting natural grassland into blue gum (Eucalyptus globules) in Nilgiri watersheds of South India', Journal of Hydrology 270(1-2) 12-26. https://doi.org/10.1016/S0022-1694(02)00172-5

Smith, J.H., Wickham, J.D., Stehman, S.V. \& Yang, L., 2002, 'Impacts of patch size and land cover heterogeneity on thematic image classification accuracy', Photogrammetric Engineering and Remote Sensing 68(1), 65-70.

Smithers, J., Gray, R., Johnson, S. \& Still, D., 2017, 'Modelling and water yield assessment of Lake Sibhayi', Water SA 43(3), 480-491. https://doi.org/10.4314/ wsa.v43i3.13

South African National Biodiversity Institute (SANBI), 2018, Vegetation map of South Africa, Lesotho and Swaziland, viewed 01 April 2020, from http://bgis.sanbi.org/ SpatialDataset/Detail/669.

South African Weather Service (SAWS), 2018, Climate date, viewed 12 February 2019, from http://www.weathersa.co.za/climate.

Statistics South Africa, 2011, Department of statistics, viewed 30 July 2019, from http://www.statssa.gov.za/?page_id=993\&id=the-msunduzi-municipality.

Thompson, M., 2018, EKZNW 27/2017: Updating the existing KZN provincial land cover map 2011 to 2017 Conditions.

United States Geological Survey (USGS), 2018, What is the Landsat satellite program and why is it important? viewed 20 June 2019, from https://www.usgs.gov/faqs/ what-landsat-satellite-program-and-why-it-important?qt-news science products=0\#qt-news_science_products.

Weitz, J. \& Demlie, M., 2014, 'Conceptual modeling of groundwater-surface water interactions in the Lake Sibayi Catchment, Eastern South Africa', Journal of Earth Science 99(2), 613-624. https://doi.org/10.1016/j.jafrearsci.2013.11.018

Woodward, C., Shumeister, J., Larsen, J., Jacobsen, G.E. \& Zawadzki, A., 2014, 'The hydrological legacy of deforestation on global wetlands', Science 346(621), 844-847. https://doi.org/10.1126/science.1260510

Yiu, T., 2019, Understanding random forest, viewed 31 January 2020, from https:// towardsdatascience.com/understandingrandom-forest-58381e0602d2.

Zurqania, H.A., Posta, C.J., Mikhailovaa, E.A., Schlautmanb, M.A. \& Sharpc, J.L., 2018 'Geospatial analysis of land use change in the Savannah River Basin using Google Earth Engine', International Journal of Applied Earth Observation Geoinformation 69, 175-185. https://doi.org/10.1016/j.jag.2017.12.006 